\title{
CYTOTOXIC PHOSPHINOARSINO AND DIPHOSPHINO Pd(II) COMPLEXES OF THIOLATE AMINO ACIDS AND GLUTATHIONE
}

\author{
Orla M. Ni Dhubhghaill ${ }^{1}$, Peter J. Sadler ${ }^{1}$ and Esther Garcia Fernandez² \\ 1 Department of Chemistry, Birkbeck College, University of London, Gordon House, \\ 29 Gordon Square, London WC1H OPP, United Kingdom \\ 2 Department of Inorganic Chemistry, University of Santiago de Compostela, Campus Universitario, \\ E-15706 Santiago de Compostela, Spain
}

\section{ABSTRACT}

The novel complexes $\left[\mathrm{Pd}\left(\mathrm{L}^{-} \mathrm{L}^{\prime}\right)(\mathrm{SR}) \mathrm{Cl}\right]$ where $\mathrm{L}^{\prime} \mathrm{L}^{\prime}$ is $\mathrm{Ph}_{2} \mathrm{PCH}_{2} \mathrm{CH}_{2} \mathrm{PPh}_{2}$ (dppe) or $\mathrm{Ph}_{2} \mathrm{AsCH}_{2} \mathrm{CH}_{2} \mathrm{PPh}_{2}$ (dadpe) and $\mathrm{RSH}$ is glutathione, L-cysteine, or $\mathrm{N}$-acetyl-L-cysteine, have been prepared and characterised. Their structures in the solid-state and in solution are discussed. The introduction of cysteine or glutathione as a ligand in these complexes greatly improved their aqueous solubility compared with the hydrophobic parent dichloro complexes. The cytotoxicities of the glutathione complexes towards the cell-lines L1210, ADJ/PC6 and CH1 were investigated. Their cytotoxicities towards L1210 cells were comparable to those of the parent dichloro complexes.

\section{ABBREVIATIONS}

dppe 1,2-diphenylphosphinoethane; dadpe 1-diphenylarsino-2-diphenylphosphinoethane $\mathrm{H}_{2}$ dmsa dimercaptosuccinic acid; GSH glutathione, $\gamma$-L-Glu-L-Cys-Gly

CysH L-cysteine; N-AcCysH N-acetyl-L-cysteine

$I C_{50}$ concentration required to kill $50 \%$ of the cells 


\section{INTRODUCTION}

Certain tetrahedral diphosphine complexes of Group 11 metals, such as $\left[\mathrm{Au}(\mathrm{dppe})_{2}\right] \mathrm{Cl}$ are highly cytotoxic and exhibit anticancer activity in some model systems. ${ }^{1}$ They appear to act by a different mechanism to cisplatin, cis- $\left[\mathrm{PtCl}_{2}\left(\mathrm{NH}_{3}\right)_{2}\right]$, attacking proteins as well as DNA. Recently we have sought to extend this series of complexes to include square-planar diphosphine complexes. $^{2}$ One of the major objectives is to increase the aqueous solubility of complexes containing hydrophobic diphosphine ligands, and in this paper we use thiolate amino acid derivatives for this purpose.

The formation of $\mathrm{Pd}(\mathrm{II})$ complexes with amino acids and peptides has been reviewed by Pettit and Bezer. ${ }^{3}$ There have been few studies on the formation of $\mathrm{Pd}(\mathrm{II})$ complexes with glutathione $\left(\gamma\right.$-L-Glu-L-Cys-Gly), ${ }^{3,4,5}$ although there are some reports of ${ }^{1} \mathrm{H}$ NMR studies on binding of GSH to other metals, eg $\mathrm{Me}_{3} \mathrm{~Pb},{ }^{6}$ mixed ligand complexes of $\mathrm{Cd}(\mathrm{II})(\mathrm{NTA}){ }^{7}$ and gold (I) drugs. ${ }^{8}$ Rabenstein and coworkers have carried out ${ }^{1} \mathrm{H}$ and ${ }^{13} \mathrm{C}$ NMR spectroscopic studies on the binding ${ }^{9}$, formation constants, ${ }^{10}$ and ligand exchange reactions ${ }^{11}$ of $\mathrm{MeHg}(\mathrm{II})$-thiol complexes with thiols such as glutathione, cysteine. There are no $X$-ray structures of metal GSH complexes, however a dimeric $\mathrm{Cu}(\mathrm{II})$ complex of GSSG has been crystallographically characterised. ${ }^{12}$ The solid state structure of the complex of $\mathrm{Pd}(\mathrm{II})$ with S-methyl-L-cysteine has been reported. ${ }^{13}$ The geometry about the metal is square planar with $\mathrm{S}, \mathrm{N}$ coordination, as has been found for Pd complexes of S-methyl-L-cysteine sulphoxide ${ }^{14}$ and S-methyl-L-cysteine methyl ester. ${ }^{15}$

We report here the preparation and characterization of novel mixed ligand $\mathrm{Pd}(\mathrm{II})$ complexes containing cysteine, $\mathrm{N}$-acetylcysteine or glutathione, and diphosphine or arsinophosphines as ligands, and their cytotoxicity against L1210, ADJ/PC6 and $\mathrm{CH} 1$ cell-lines. 
<smiles></smiles>

Glutathione (GSH): $\quad \gamma-$ L-Glu-L-Cys-Gly<smiles>CCC(N)C(=O)O</smiles>

SH

\section{EXPERIMENTAL SECTION}

1,2-Bis(diphenylphosphino)-ethane (dppe) and 1-diphenylphosphino-2-diphenylarsinoethane (dadpe) were purchased from Strem Chemicals. L-Cysteine (free base), $\mathrm{N}$-acetyl-L-cysteine, and

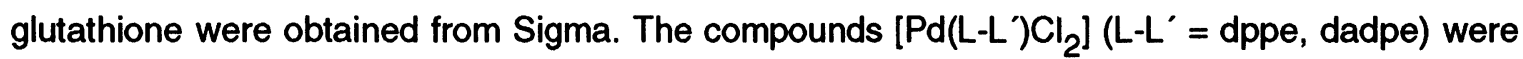
prepared from dichloro-1,5-cyclooctadiene-palladium(II) (Aldrich) as previously described for the analogous $\mathrm{Pt}$ complex, ${ }^{16}$ and isolated as $\mathrm{CHCl}_{3}$ solvates, $\left[\mathrm{Pd}\left(\mathrm{L}^{-} \mathrm{L}^{\prime}\right) \mathrm{Cl}_{2}\right] \cdot 2 \mathrm{CHCl}_{3}$.

\section{Physical measurements}

$500 \mathrm{MHz}{ }^{1} \mathrm{H}$ NMR spectra were recorded at ambient temperature $\left(\mathrm{ca} .23^{\circ} \mathrm{C}\right)$ on a JEOL GSX500 instrument. ${ }^{13} \mathrm{C}\left\{{ }^{1} \mathrm{H}\right\}$ NMR spectra were recorded on a JEOL GSX270 spectrometer operating at 71.9 MHz; $81 \mathrm{MHz}{ }^{31} \mathrm{P}\left\{{ }^{1} \mathrm{H}\right\}$ spectra were acquired on a Bruker WM200 spectrometer. ${ }^{1} \mathrm{H}$ and ${ }^{13} \mathrm{C}$ chemical shifts were referenced to sodium trimethylsilyl-2,2,3,3- $d_{4}$-propionate (TSP), and ${ }^{31} \mathrm{P}$ shifts to external $85 \% \mathrm{H}_{3} \mathrm{PO}_{4}$.

Measurements of $\mathrm{pH}^{\star}$ ( $\mathrm{pH}$ meter reading in $\mathrm{D}_{2} \mathrm{O}$ solutions) were made on a Corning $\mathrm{pH}$ meter equipped with an Aldrich combination microelectrode. Adjustments of $\mathrm{pH}^{\star}$ were made with $\mathrm{DCl}$ or $\mathrm{NaOD}$.

IR spectra were recorded on a Perkin-Elmer 1330 instrument as Nujol mulls for GSH and its complexes, and $[\mathrm{Pd}($ dadpe $)(\mathrm{NAcCys}) \mathrm{Cl}]$, and as $\mathrm{KBr}$ discs for $\mathrm{CysH}$ and $[\mathrm{Pd}(\mathrm{dppe})(\mathrm{Cys}) \mathrm{Cl}]$. For 
[Pd(dadpe)(Cys)Cl] a $\mathrm{KBr}$ disc was used between 4000 and $600 \mathrm{~cm}^{-1}$ and a Nujol mull between 600 and $200 \mathrm{~cm}^{-1}$.

Mass spectra (fast atom bombardment) were recorded using a VG ZAB-SE mass spectrometer at the University of London School of Pharmacy (ULIRS) with samples in an MNOBA (meta-nitroortho-benzoic acid) matrix. Elemental analyses were carried out by the microanalysis service at University College London.

Thin layer chromatography was carried out on RPS-F plates (Anachem) using 1:1 $\mathrm{EtOH}: \mathrm{H}_{2} \mathrm{O}$ as eluant. Cysteine complexes were dissolved in $\mathrm{EtOH}$ or $\mathrm{H}_{2} \mathrm{O}$ prior to elution and glutathione complexes in $\mathrm{H}_{2} \mathrm{O}$.

\section{Synthesis of $[\mathrm{Pd}(\mathrm{dpp \theta})(\mathrm{Cys} . \mathrm{HCl}) \mathrm{Cl}] \cdot \mathrm{H}_{2} \mathrm{O}(1)$}

To a suspension of $\left[\mathrm{Pd}(\mathrm{dppe}) \mathrm{Cl}_{2}\right] \cdot 2 \mathrm{CHCl}_{3}(0.099 \mathrm{~g}, 0.12 \mathrm{mmol})$ in aq. $\mathrm{EtOH}(30 \mathrm{~mL}, 1: 2)$ was added an aqueous solution $(5 \mathrm{~mL})$ of L-CysH $(0.014 \mathrm{~g}, 0.12 \mathrm{mmol})$. After stirring at room temperature for $1 \mathrm{~h}$, the solution had become yellow with some solid present. It was filtered, then concentrated affording a yellow solid $1(0.0145 \mathrm{~g}, 17 \%)$, m.p. $170{ }^{\circ} \mathrm{C}$.

(Found: $\mathrm{C}, 47.0 ; \mathrm{H}, 4.6 ; \mathrm{N}, 2.2 ; \mathrm{P}, 9.1 \% ; \mathrm{C}_{29} \mathrm{H}_{33} \mathrm{NO}_{3} \mathrm{SP}_{2} \mathrm{Cl}_{2} \mathrm{Pd}$ requires : $\mathrm{C}, 48.7 ; \mathrm{H}, 4.65 ; \mathrm{N}$, 2.0; P, $8.7 \%$ ); IR data, Table $1 ;{ }^{31} \mathrm{P}$ and ${ }^{1} \mathrm{H}$ NMR data, Tables 2 and $3 ; \mathrm{m} / \mathrm{z} 624$ $\left\{[\mathrm{Pd}(\mathrm{dppe}) \mathrm{Cys}]^{+}\right\}$. TIc: $R_{f}=0.64$ EtOH solution; $R_{f}=0.58$ and faint spot at $R_{f}=0.83$ aq. solution)

\section{Synthesis of $[\mathrm{Pd}($ dadpe $)($ Cys. $\mathrm{HCl}) \mathrm{Cl}] \cdot \mathrm{H}_{2} \mathrm{O}(2)$}

To a suspension of $\left[\mathrm{Pd}(\right.$ dadpe $\left.) \mathrm{Cl}_{2}\right] \cdot 2 \mathrm{CHCl}_{3}(0.202 \mathrm{~g}, 0.235 \mathrm{mmol})$ in aq. $\mathrm{EtOH}(30 \mathrm{~mL}, 1: 2)$ was

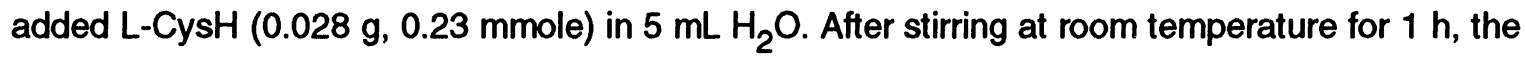
almost clear yellow solution was filtered and the filtrate concentrated affording an orange-yellow solid 2. $(0.137 \mathrm{~g}, 77 \%)$.

(Found: $\mathrm{C}, 45.5 ; \mathrm{H}, 4.3 ; \mathrm{N}, 1.7 ; \mathrm{P}, 4.6 \% ; \mathrm{C}_{29} \mathrm{H}_{33} \mathrm{NO}_{3} \mathrm{SPAsCl}_{2} \mathrm{Pd}$ requires: $\mathrm{C}, 45.9 ; \mathrm{H}, 4.4 ; \mathrm{N}$, 
1.85; P, $4.1 \%)$; IR data, Table 1; ${ }^{31} \mathrm{P}$ NMR data, Table $2 ; m / z \quad 670\left\{[\mathrm{Pd}(\text { dadpe })(\mathrm{Cys} H)]^{+}+1\right\}$. Tlc $: R_{f}=0.71$ and 0.69 for EtOH and $\mathrm{H}_{2} \mathrm{O}$ solutions, respectively)

\section{Synthesis of $[\mathrm{Pd}(\mathrm{dppe})(\mathrm{GS} . \mathrm{HCl}) \mathrm{Cl}] .3 \mathrm{H}_{2} \mathrm{O}$ (3)}

To a suspension of $\left[\mathrm{Pd}(\mathrm{dppe}) \mathrm{Cl}_{2}\right] \cdot 2 \mathrm{CHCl}_{3}(0.166 \mathrm{~g}, 0.203 \mathrm{mmol})$ in aq. $\mathrm{EtOH}(30 \mathrm{~mL}, 1: 2)$ was added an aqueous solution $(10 \mathrm{~mL})$ of $\mathrm{GSH}(0.071 \mathrm{~g}, 0.229 \mathrm{mmol})$. After stirring at room temperature for $1 \mathrm{~h}$, the solution had become almost clear yellow. It was filtered, then concentrated affording a yellow solid $3(0.141 \mathrm{~g}, 73.9 \%)$, m.p. $125^{\circ} \mathrm{C}$.

(Found: $\mathrm{C}, 45.6 ; \mathrm{H}, 4.8 ; \mathrm{N}, 4.45 \% ; \mathrm{C}_{36} \mathrm{H}_{47} \mathrm{~N}_{3} \mathrm{O}_{9} \mathrm{PdSCl}_{2} \mathrm{P}_{2}$ requires: $\mathrm{C}, 46.2 ; \mathrm{H}, 5.0 ; \mathrm{N}, 4.5 \%$ ); IR data, Table $1 ;{ }^{31} \mathrm{P},{ }^{1} \mathrm{H}$ and ${ }^{13} \mathrm{C}$ NMR data, Tables 2,3 and $4 ; m / z \quad 811\left\{[\mathrm{Pd}(\mathrm{dppe})(\mathrm{GSH})]^{+}+\right.$ 1\}; tlc, $\mathrm{R}_{f}=0.08$ for $\mathrm{H}_{2} \mathrm{O}$ solution)

\section{Synthesis of $[\mathrm{Pd}(\mathrm{dadpe})(\mathrm{GS} . \mathrm{HCl}) \mathrm{Cl}] .3 \mathrm{H}_{2} \mathrm{O}$ (4)}

To a suspension of $\left[\mathrm{Pd}(\right.$ dadpe $\left.) \mathrm{Cl}_{2}\right] \cdot 2 \mathrm{CHCl}_{3}(0.209 \mathrm{~g}, 0.245 \mathrm{mmol})$ in aq. $\mathrm{EtOH}(30 \mathrm{~mL}, 1: 2)$ was added GSH $(0.074 \mathrm{~g}, 0.241 \mathrm{mmole})$ in $10 \mathrm{~mL} \mathrm{H}_{2} \mathrm{O}$. After stirring at room temperature for $1 \mathrm{~h}$, the resultant clear yellow solution was filtered and the filtrate concentrated affording an orange-yellow solid 4 (0.137 g, 58 \%), m.p. $155-160^{\circ} \mathrm{C}$, (Found: C, 43.3; H, 4.6; N, 4.3; Cl, 7.1; P, $3.4 \%$; $\mathrm{C}_{36} \mathrm{H}_{47} \mathrm{~N}_{3} \mathrm{O}_{9} \mathrm{PdSCl}_{2} \mathrm{PAs}$ requires: $\mathrm{C}, 44.1 ; \mathrm{H}, 4.8 ; \mathrm{N}, 4.3 ; \mathrm{Cl}, 7.2 ; \mathrm{P}, 3.2 \%$ ); IR data, Table 1; ${ }^{31} \mathrm{P}$ and ${ }^{13} \mathrm{C}$ NMR data, Tables 2 and $4 ; m / z \quad 855\left\{[\mathrm{Pd}(\text { dadpe })(G S H)]^{+}+1\right\} ;$ tlc $: R_{f}=0.15$ for $\mathrm{H}_{2} \mathrm{O}$ solution (streaking).

\section{Synthesis of $[\mathrm{Pd}($ dadpe $)(\mathrm{N}-\mathrm{AcCys}) \mathrm{Cl}] . \mathrm{H}_{2} \mathrm{O}$ (5)}

To a suspension of $\left[\mathrm{Pd}(\right.$ dadpe $\left.) \mathrm{Cl}_{2}\right] .2 \mathrm{CHCl}_{3}(0.10 \mathrm{~g}, 0.116 \mathrm{mmol})$ in $\mathrm{EtOH}(25 \mathrm{~mL})$ was added an aqueous solution $(3 \mathrm{~mL})$ of $\mathrm{N}$-Ac Cys $(0.019 \mathrm{~g}, 0.116 \mathrm{mmol})$. After stirring at room temperature for $30 \mathrm{~min}$, the solution had become almost clear yellow. It was filtered, then concentrated in vacuo affording a yellow solid $5(0.053 \mathrm{~g}, 60.8 \%)$, m.p. $145-150^{\circ} \mathrm{C}$.

(Found, C, 48.6; $\mathrm{H}, 4.7 ; \mathrm{N}, 1.9 ; \mathrm{P}, 4.3 \% . \mathrm{C}_{31} \mathrm{H}_{34} \mathrm{NO}_{4}$ SPdPAsCl requires: $\mathrm{C}, 48.7 ; \mathrm{H}, 4.5 ; \mathrm{N}, 1.8$; 
P. $4.1 \%) ;{ }^{31} \mathrm{P}$ NMR data, Table 2.

Reactions of $\left[\mathrm{Pd}(\mathrm{dppe}) \mathrm{Cl}_{2}\right] \cdot 2 \mathrm{CHCl}_{3}$ with $\mathrm{NAcCysH}$ were also carried out, but it was not possible to isolate a pure product.

\section{Biological testing}

The cytotoxicities of aqueous solutions of the glutathione complexes 3 and 4 against murine L1210 and ADJ/PC6, and normal CH1 (human ovarian cells) cell-lines were determined as described previously. ${ }^{2}$

\section{RESULTS AND DISCUSSION}

There are a few previous reports of $\mathrm{Pd}(\mathrm{II})$ complexes with anticancer activity. ${ }^{17,18}$ In general $\mathrm{Pd}(\mathrm{II})$ complexes are much more kinetically labile than those of $\mathrm{Pt}(\mathrm{II})$ and therefore less likely to arrive at the target site (e.g. DNA) with the original ligands still bound. However in the present case intracellular ligand release might still result in activity since the ligands dppe and dadpe are themselves cytotoxic. ${ }^{2}$ The main aim of the present work was to increase the aqueous solubility of $\mathrm{Pd}(\mathrm{II})$ complexes containing these hydrophobic ligands whilst retaining their cytotoxicity.

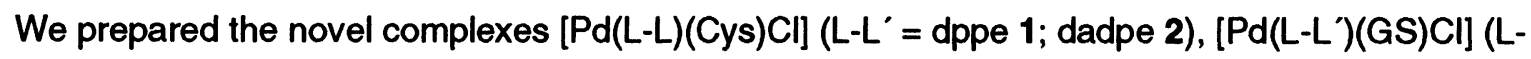
$L^{\prime}=$ dppe 3; dadpe 4) and $[\mathrm{Pd}(\mathrm{L}-\mathrm{L})(\mathrm{N}-\mathrm{AcCys}) \mathrm{Cl}]\left(\mathrm{L}^{-L^{\prime}}=\right.$ dadpe 5$)$ by addition of an aqueous solution of the thiol ligand to an aqueous ethanolic suspension of $\left[\mathrm{Pd}(\mathrm{L}-\mathrm{L}) \mathrm{Cl}_{2}\right]$. The complexes have satisfactory element analyses, except for the low $C$ content of complex 1 . The mass spectra of complexes 1 to 4 were consistent with the proposed formulae and the presence of monomeric structures in the solid state. Only for complex 2, $[\mathrm{Pd}($ dadpe $)(\mathrm{Cys} . \mathrm{HCl}) \mathrm{Cl}]$, was a significant amount of a higher molecular mass ion observed, and this was only a minor 
TABLE 1. IR data for $\left[\mathrm{Pd}\left(\mathrm{L}^{-L^{\prime}}\right)(\mathrm{Cys} . \mathrm{HCl}) \mathrm{Cl}\right]\left(\mathrm{L}^{-L^{\prime}}=\right.$ dppe 1; dadpe 2) and $\left[\mathrm{Pd}\left(\mathrm{L}^{-L^{\prime}}\right)(\mathrm{GS} . \mathrm{HCl}) \mathrm{Cl}\right]$ ( $L-L^{\prime}=$ dppe 3; dadpe 4) and the thiol ligands. (vs very strong, s strong, m medium, w weak, br broad)

\begin{tabular}{|c|c|c|c|c|c|c|}
\hline CysH & 1 & 2 & GSH & 3 & 4 & Assignment \\
\hline $3460(m, b r)$ & $3430(\mathrm{~m}, \mathrm{br})$ & $3450(m, b r)$ & & $3400(w, b r)$ & $3400(w, b r)$ & $v(\mathrm{O}-\mathrm{H})$ of $\mathrm{H}_{2} \mathrm{O}$ \\
\hline & & & 3330 vs & & & \\
\hline 3180 vs & & & 3240 vs & & & $v(\mathrm{~N}-\mathrm{H})$ \\
\hline 3000 (s, br) & $3060(\mathrm{~m}, \mathrm{br})$ & $3050 w$ & $3120 \mathrm{~s}$ & -1 & -1 & \\
\hline $2550 \mathrm{~m}$ & absent & absent & $2515 \mathrm{~s}$ & absent & absent & $v(\mathrm{~S}-\mathrm{H})$ \\
\hline . & $1725(\mathrm{~s}, \mathrm{br})$ & $1725(\mathrm{~s}, \mathrm{br})$ & 1710 vs & $1720 \mathrm{~m}$ & $1715(\mathrm{~m}, \mathrm{br})$ & $v(C=O)$ \\
\hline 1600 (vs, br) & 1635 (vs, br) & $1625(\mathrm{~m}, \mathrm{br})$ & 1650 vs & $1650(\mathrm{~s}, \mathrm{br})$ & $1650(\mathrm{~m}, \mathrm{br})$ & $\delta_{d}\left(\mathrm{NH}_{3}^{+}\right)$ \\
\hline 1580 (vs, br) & absent & absent & $1600(s, b r)$ & absent & absent & $\mathrm{v}\left(\mathrm{COO}^{-}\right)_{\text {asym }}$ \\
\hline $1515 \mathrm{~s}$ & $1480 \mathrm{~s}$ & $1470 \mathrm{~m}$ & $1525(\mathrm{~s}, \mathrm{br})$ & $1515(w, b r)$ & $1510(w, b r)$ & $\delta\left(\mathrm{NH}_{3}{ }^{+}\right)_{\text {sym }}$ \\
\hline $1415 \mathrm{~s}$ & $1430 \mathrm{~s}$ & $1425 \mathrm{~s}$ & $1405 m$ & -1 & .1 & $\begin{array}{l}v\left(\mathrm{COO}^{-}\right)_{\text {sym }} \\
v(\mathrm{C}-\mathrm{O}) / \\
\delta(\mathrm{O}-\mathrm{H}) \text { in-plane }\end{array}$ \\
\hline $940 \mathrm{~s}$ & $930(w, b r)$ & absent & $920 \mathrm{~s}$ & absent & absent & $\begin{array}{l}\delta(\mathrm{S}-\mathrm{H}) / \delta(\mathrm{O}-\mathrm{H}) \\
\text { out-of-plane }\end{array}$ \\
\hline
\end{tabular}

1 Overlap with Nujol

component. The mass spectrum of 1 showed a parent molecular ion (p.m.i) of m/e 624 corresponding to $[\mathrm{Pd}(\mathrm{dppe})(\mathrm{Cys})]^{+}$which is also the most intense or base peak. For 2 the base peak was at $\mathrm{m} / \mathrm{z}=670$, which is assigned to $[\mathrm{Pd}(\text { dadpe })(\mathrm{CysH})]^{+}+1$; there were also a number of higher mass peaks, the most abundant being $\mathrm{m} / \mathrm{z}=1261\left([\mathrm{Pd}(\text { dadpe })(\mathrm{CysH})]_{2}^{+}-\mathrm{Ph}+1 ; 20 \%\right.$ intensity of base peak). Complexes 3 and 4 showed p.m.i.'s at $\mathrm{m} / \mathrm{z}=811$ and 855 corresponding to $[\mathrm{Pd}(\mathrm{dppe})(\mathrm{GSH})]^{+}+1$ and $[\mathrm{Pd}(\mathrm{dadpe})(\mathrm{GSH})]^{+}+1$, respectively. The base peaks for these two complexes are assignable to a species $\left[\mathrm{Pd}(\mathrm{L}-\mathrm{L})\left(\mathrm{SH}_{2}\right)\right]^{+}+1$. The IR spectra for complexes 1-4, Table 1, showed the disappearance of the SH stretch confirming that the thiol ligands are coordinated via S. 
TABLE 2. ${ }^{31} \mathrm{P}\left\{{ }^{1} \mathrm{H}\right\}$ NMR data for $\left[\mathrm{Pd}\left(\mathrm{L}^{-} \mathrm{L}^{\prime}\right)(\mathrm{Cys} . \mathrm{HCl}) \mathrm{Cl}\right]$, and $\left[\mathrm{Pd}\left(\mathrm{L}^{-L^{\prime}}\right)(\mathrm{GSH} . \mathrm{HCl}) \mathrm{Cl}\right]$ in $\mathrm{D}_{2} \mathrm{O}$ at various $\mathrm{pH}^{*}$ values and in $\mathrm{d}_{6}$-dmso, and for $\left[\mathrm{Pd}\left(\right.\right.$ dadpe)(NAc-Cys)Cl] 5 in $\mathrm{EtOH} / \mathrm{D}_{2} \mathrm{O}$. (L-L' $=$ dppe, dadpe) and some tentative assignments.

\begin{tabular}{|c|c|c|c|c|c|}
\hline Complex & Solvent & $\mathrm{pH}^{*}$ & $\delta(p p m)$ & $J(H z)$ & Group trans to $P$ \\
\hline \multirow[t]{9}{*}[\mathrm{Pd}(\mathrm{dppe})(\mathrm{Cys})\mathrm{Cl}]{1} & $\mathrm{D}_{2} \mathrm{O}$ & 2.7 & 65.4 & - & $S$ bridging \\
\hline & & & 64.2 & 18.6 & $\mathrm{Cl} / \mathrm{N}$ \\
\hline & & & 55.7 & 18.7 & S \\
\hline & & 7.1 & 63.3 & 19.0 & $\mathrm{Cl} / \mathrm{N}$ \\
\hline & & & 54.9 & 19.4 & S \\
\hline & & 12.2 & 63.3 & 19.0 & $\mathrm{Cl} / \mathrm{N}$ \\
\hline & & & 54.9 & 19.1 & S \\
\hline & $d_{6}$-dmso & - & 62.6 & 22.9 & $\mathrm{Cl} / \mathrm{N}$ \\
\hline & & - & 51.0 & 23.0 & S \\
\hline \multirow[t]{8}{*}[\mathrm{Pd}(\text{dadpe})(\text{Cys})\mathrm{Cl}]{2} & $\mathrm{D}_{2} \mathrm{O}$ & 2.6 & $68.5(b r)$ & - & $S$ bridging \\
\hline & & & 64.9 & - & $\mathrm{Cl} / \mathrm{N}$ \\
\hline & & & 58.7 & - & S \\
\hline & & 7.1 & $64.3(80 \%)$ & - & $\mathrm{Cl} / \mathrm{N}$ \\
\hline & & & $58.2(20 \%)$ & - & S \\
\hline & & 12.2 & $64.3(90 \%)$ & - & $\mathrm{Cl} / \mathrm{N}$ \\
\hline & & & $58.0(10 \%)$ & - & S \\
\hline & $d_{6}-d m s o$ & & 63.7 & - & $\mathrm{Cl} / \mathrm{N}$ \\
\hline \multirow[t]{6}{*}{ [Pd(dppe)(GS)Cl] 3} & $\mathrm{D}_{2} \mathrm{O}$ & 2.5 & 65.1 & - & $S$ bridging \\
\hline & & 7.1 & 64.8 & - & $S$ bridging \\
\hline & & 12.5 & $\begin{array}{l}61.0,52.2,49.5 \\
(50: 30: 20 \%)\end{array}$ & - & \\
\hline & $d_{6}-d m s o$ & - & 66.4 & 11.9 & $\mathrm{Cl} / \mathrm{N}$ \\
\hline & & & 54.2 & 11.9 & S \\
\hline & & & $67.4,56.9$ (weak) & - & \\
\hline \multirow[t]{5}{*}{ [Pd(dadpe)(GS)Cl] 4} & $\mathrm{D}_{2} \mathrm{O}$ & 2.5 & 67.5 & - & $\mathrm{Cl} / \mathrm{N}$ \\
\hline & & 7.1 & 67.2 & - & $\mathrm{Cl} / \mathrm{N}$ \\
\hline & & 12.4 & $63.7,62.9,62.4$ & - & \\
\hline & $d_{6}-d m s o$ & & $68.8(92 \%)$ & - & $\mathrm{Cl} / \mathrm{N}$ \\
\hline & & & $58.8(8 \%)$ & - & S \\
\hline
\end{tabular}

$\left[\mathrm{Pd}(\right.$ dadpe)$(\mathrm{NAc}-\mathrm{Cys}) \mathrm{Cl}] 5 \quad \mathrm{EtOH} / \mathrm{D}_{2} \mathrm{O} \quad 67.2,66.2-$ 
TABLE 3. ${ }^{1} \mathrm{H}$ NMR data for the complexes [Pd(dppe)(Cys)Cl] 1 and $[\mathrm{Pd}(\mathrm{dppe})(\mathrm{GS}) \mathrm{Cl}] 3$ in $\mathrm{D}_{2} \mathrm{O}$. (dd doublet of doublets, $t$ triplet, m multiplet, br broad $\Delta v_{1 / 2} 40-100 \mathrm{~Hz}$ ).

\begin{tabular}{|c|c|c|c|}
\hline Complex & $\delta(p p m)$ & $\delta(p p m)$ & Assignment \\
\hline \multirow[t]{2}{*}[\mathrm{Pd}(\mathrm{dppe})(\mathrm{Cys})\mathrm{Cl}]{1} & $\mathrm{pH}^{*}=2.7$ & $\mathrm{pH}^{\star}=7.1$ & \\
\hline & $\begin{array}{l}7.875,7.675 \\
7.600,7.574 \mathrm{~m} \\
4.224 \mathrm{~m} \\
2.942 \mathrm{~m} \\
2.718 \mathrm{~m}\end{array}$ & $\begin{array}{l}7.825,7.733 \\
7.648,7.574 \mathrm{~m} \\
3.814 \mathrm{~m} \\
2.862 \mathrm{~m} \\
2.778,2.711 \\
2.607 \mathrm{~m}\end{array}$ & $\begin{array}{l}\text { Cys } \alpha-\mathrm{CH} \\
\text { Cys } \beta-\mathrm{CH}_{2} \\
\text { dppe } \mathrm{CH}_{2}\end{array}$ \\
\hline \multirow[t]{6}{*}[\mathrm{Pd}(\mathrm{dppe})(\mathrm{GS})\mathrm{Cl}]{3} & $\mathrm{pH}^{*}=2.5$ & $\mathrm{pH}^{*}=7.1$ & \\
\hline & $7.88,7.68$ & $7.89,7.64$ & $\mathrm{C}_{6} \mathrm{H}_{5}$-of dppe \\
\hline & $\begin{array}{l}7.55,7.47 \\
7.39 \mathrm{br}\end{array}$ & $\begin{array}{l}7.50,7.41 \\
7.34 \mathrm{br}\end{array}$ & \\
\hline & $3.763 \mathrm{q}$ & $3.657 t$ & Gly- $\alpha \mathrm{CH}_{2}$ \\
\hline & $3.724 \mathrm{dd}$ & $\begin{array}{l}3.570 \\
3.388\end{array}$ & Glu- $\alpha \mathrm{CH}$ \\
\hline & $\begin{array}{l}3.32 \mathrm{br} \\
2.85 \mathrm{br} \\
2.52 \mathrm{br} \\
2.231,2.047 \mathrm{~m} \\
1.966 \mathrm{~m}\end{array}$ & $\begin{array}{l}3.27 \mathrm{br} \\
2.82 \mathrm{br} \\
2.443 \mathrm{br} \\
2.22,2.00 \mathrm{~m}\end{array}$ & $\begin{array}{l}\text { Cys- } \beta \mathrm{CH}_{2} \\
\text { Glu- } \gamma \mathrm{CH}_{2} \\
\text { Glu- } \beta \mathrm{CH}_{2} \\
\mathrm{CH}_{2} \text { of dppe }\end{array}$ \\
\hline
\end{tabular}

In solution the structures of these complexes are potentially complicated since $\mathrm{Pd}(\mathrm{II})$ can form strong bonds to $\mathrm{Cl}^{-}$, thiolate $\mathrm{S}$, carboxylate $\mathrm{O}$, and amino or deprotonated amide $\mathrm{N}$ atoms. We made some tentative structural assignments from ${ }^{31} \mathrm{P},{ }^{1} \mathrm{H}$ and ${ }^{13} \mathrm{C}$ NMR data. ${ }^{31} \mathrm{P}$ NMR is particularly useful for dppe complexes since the presence of a ${ }^{31} \mathrm{P}_{-}{ }^{31} \mathrm{P}$ coupling indicates a complex with non-equivalent coordinated $\mathrm{P}$ atoms and the shifts are a guide to the nature of the trans ligand, based on those of previously-reported chloro ( $\delta 64.2 \mathrm{ppm})$ and S-bound dmsa ( $\delta$ 


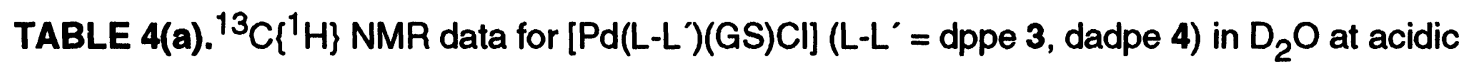
and neutral $\mathrm{pH}^{\star}$ values. $\Delta \delta=\delta\left(\mathrm{pH}^{*} 7.2\right)-\delta\left(\mathrm{pH}^{\star} 1.8\right)$ and some tentative assignments.

\section{Complex}

[Pd(dppe)(GS)Cl] 3

$\mathrm{pH}^{\star} 1.8$

176.1

175.5

175.1

173.0

$136.5,135.8$

$132.7,132.5$

$129.0,128.2,127.3$

56.8

55.6

43.8

35.1

34.1

$30.1 \mathrm{~d}$

28.4

[Pd(dadpe)(GS)Cl] 4

$\mathrm{pH}^{\star} 1.8$

176.0

175.5

175.0

173.3

172.9

172.5

$136.7,136.3$

$135.6,135.2$

56.8

55.4

43.8

36.7

$36.5(\mathrm{~d} 14.4 \mathrm{~Hz})$

34.0

$31.0(\mathrm{~d} 27.3 \mathrm{~Hz})$

28.4
$\mathrm{pH}^{\star} 7.2$

176.6

178.4

176.4

172.0

136.6, 135.9, 135.5

132.9, 132.5 (d $6.4 \mathrm{~Hz})$

129.2 br, 128.1, 127.3

56.8

56.8

46.1

35.4

34.5

$30.0(\mathrm{~d} 36.7 \mathrm{~Hz})$

29.0

$\mathrm{pH}^{\star} 7.2$

176.7

178.3

176.4

172.3

172.0

171.5

$136.9,136.8$

$136.3,136.1,135.9$

56.8

56.8

46.0

34.4

29.0
$\Delta \delta$ (complex) $\Delta \delta(G S H) \quad$ Assignment

0.5

0.4

Glu $\gamma$-CONH

2.9

3.3

1.3

1.6

$-1.0$

$-0.8$

Gly- $\alpha \mathrm{COOH}$

Glu- $\alpha \mathrm{COOH}$

Cys- $\alpha \mathrm{CONH}$

dppe $\mathrm{Ph}$

0

0.1

Cys- $\alpha \mathrm{CH}$

1.2

1.2

2.2

0.2

0.3

0.4

0.4

0.6

0.5

Glu- $\alpha \mathrm{CH}$

Gly- $\alpha \mathrm{CH}_{2}$ Cys- $\mathrm{\beta CH}_{2}$

Glu- $\mathrm{CH}_{2}$

$\mathrm{CH}_{2}-\mathrm{P}$

Glu- $\beta \mathrm{CH}_{2}$

$\begin{array}{lll}0.7 & 0.4 & \text { Glu } \gamma-\mathrm{CONH} \\ 2.8 & 3.3 & \text { Gly- } \alpha \mathrm{COOH} \\ 1.4 & 1.6 & \text { Glu- } \alpha \mathrm{COOH} \\ -1.8 & -1.0 & \text { Cys- } \alpha \mathrm{CONH} \\ -0.9 & & \end{array}$

dadpe $\mathrm{Ph}$

$-1.0$

0

0.1

Cys- $\alpha \mathrm{CH}$

1.4

1.2

Glu- $\alpha \mathrm{CH}$

2.2

2.2

Gly- $\alpha \mathrm{CH}_{2}$

0.2

Cys- $\mathrm{\beta CH}_{2}$

$\mathrm{CH}_{2}$-As

0.4

0.4

Glu- $\mathrm{CH}_{2}$

$\mathrm{CH}_{2}-\mathrm{P}$

0.6

0.5

Glu- $\beta \mathrm{CH}_{2}$ 
TABLE 4(b). ${ }^{13} \mathrm{C}$ Coordination chemical shifts (ccs) for [Pd(dppe)(GS)Cl] 3 and

$\left[\mathrm{Pd}\left(\right.\right.$ dadpe)(GS)Cl] 4 at $\mathrm{pH}^{*} 1.8$ and 7.2 (upfield shifts are negative)

\begin{tabular}{llr} 
& \multicolumn{2}{c}{ Coordination chemical shifts (ppm) } \\
Group & Complex 3 & Complex 4
\end{tabular}

$\begin{array}{lcrrr} & \mathrm{pH}^{*}=1.8 & \mathrm{pH}^{*}=7.2 & \mathrm{pH}^{*}=1.8 & \mathrm{pH}^{*}=7.2 \\ \text { Glu } \gamma-\mathrm{CONH} & -1.2 & -1.1 & -1.3 & -1.0 \\ \text { Gly- } \alpha \mathrm{COOH} & -0.2 & -0.6 & -0.2 & -0.7 \\ \text { Glu- } \alpha \mathrm{COOH} & 0 & -0.3 & -0.1 & -0.3\end{array}$

$\begin{array}{lcccc} & & & -1.9 & -2.1 \\ \text { Cys- } \alpha \mathrm{CONH} & -2.2 & -2.4 & -2.3 & -2.4 \\ & & & -2.7 & -2.9 \\ \text { Cys- } \alpha \mathrm{CH} & -1.5 & -1.6 & -1.5 & -1.6 \\ \text { Glu- } \alpha \mathrm{CH} & -0.1 & -0.1 & -0.3 & -0.1 \\ \text { Gly- } \alpha \mathrm{CH}_{2} & -0.1 & 0 & -0.1 & -0.1 \\ \text { Cys- } \beta \mathrm{CH}_{2} & 7.0 & 7.1 & 8.6 & -1 \\ \text { Glu- } \mathrm{CH}_{2} & 0.3 & 0.3 & 0.2 & 0.2 \\ \text { Glu- } \beta \mathrm{BCH}_{2} & 0 & 0.1 & 0 & 0.1\end{array}$

1 uncertain unassignment

$54.4 \mathrm{ppm}$ ) complexes. However based on the present data alone a distinction between $\mathrm{N}$ and $\mathrm{Cl}$ binding was not possible.

${ }^{31} \mathrm{P}$ NMR data are given in Table 2. For complex 1 at low $\mathrm{pH}^{*}$ two species were present in solution, one of which contained magnetically equivalent $P$ atoms $(\delta=65.4 ; 1 \mathrm{a})$ and the other $(\delta=$ 64.2, 55.7; 1b) non-equivalent $P$ atoms. The coupling constant of $19 \mathrm{~Hz}$ is typical of ${ }^{3} \mathrm{~J}$ (PP) values in square-planar complexes. ${ }^{2}$ At higher $\mathrm{pH}^{*}$ and in $\mathrm{d}_{6}$-dmso only $\mathbf{1 b}$ was present. This suggests that complex $1 \mathbf{a}$ is a symmetrical thiolate S-bridged dimer $[\mathrm{Pd}(\mathrm{dppe})(\mu-\mathrm{Cys}-\mathrm{S})]_{2}$. It seems likely that complex $1 \mathrm{~b}$ is present in dmso as $[\mathrm{Pd}(\mathrm{dppe})(\mathrm{Cys}-\mathrm{S}) \mathrm{Cl}]$ and in aqueous solution 1b has a chelated Cys ligand as in $\left[\mathrm{Pd}(\mathrm{dppe})(\mathrm{Cys}-S, M]\right.$. At high $\mathrm{pH}^{*}$, the spectrum of 2 showed 
two resonances at 64.3 and $58.0 \mathrm{ppm}$. Since there is only one $\mathrm{P}$ atom in the dadpe ligand, these are assigned to two isomeric species, the latter to a $P$ trans to $S$ by analogy with $[\mathrm{Pd}(\mathrm{dadpe})(\mathrm{dmsa})](57.3 \mathrm{ppm})^{2}$, and the former to the predominant isomer containing $\mathrm{P}$ trans to $\mathrm{N}$ or $\mathrm{Cl}$. At low $\mathrm{pH}^{*}$ a third peak is present assignable to a species containing bridging $\mathrm{S}$, and the intensity of the peak for the major isomer increased by a factor of ca. 4 .

A pure product was not isolated from the reaction of $\left[\mathrm{Pd}(\mathrm{dppe}) \mathrm{Cl}_{2}\right]$ with $\mathrm{N}$-acetyl-L-cysteine; the ${ }^{31} \mathrm{P}$ NMR spectrum of an aqueous EtOH solution of the crude product showed that only a species containing magnetically equivalent $\mathrm{P}$ atoms was present. Complex 5, $[\mathrm{Pd}($ dadpe $)(\mathrm{NAcCys}) \mathrm{Cl}]$ gave two resonances at $76.2 \mathrm{ppm}$ and $66.2 \mathrm{ppm}$ in aqueous $\mathrm{EtOH}$.

${ }^{1} \mathrm{H}$ NMR data for complexes 1 and 3 are listed in Table 3 . For complex 1 at low $\mathrm{pH}^{*}$ there are resonances at 4.22 and $2.94 \mathrm{ppm}$ due to the $\alpha-\mathrm{CH}$ and $\beta-\mathrm{CH}_{2}$ of coordinated Cys. At neutral pH, these are less shifted with respect to unbound Cys, in particular that of the $\alpha-\mathrm{CH}$, suggesting that either the carboxylate or the amino group is uncoordinated and protonates at low $\mathrm{pH}$. At both $\mathrm{pH}$ values, the ${ }^{1} \mathrm{H}$ NMR spectra showed minor signals characteristic of cystine and free Cys which shifted slightly downfield as the $\mathrm{pH}^{\star}$ was increased. The spectra at low $\mathrm{pH}^{\star}$ also showed four multiplets at 7.88-7.57 ppm due to the $\mathrm{C}_{6} \mathrm{H}_{5}$ protons of dppe, and a broad multiplet at 2.718 p.p.m. due to the $\mathrm{CH}_{2}$ protons of dppe. At higher $\mathrm{pH}^{*}$ the $\mathrm{Ph}$ resonances were unchanged and the $\mathrm{CH}_{2}$ protons gave rise to three multiplets. The spectrum of 3 at low $\mathrm{pH}^{*}$ showed a quartet assignable to Gly- $\alpha-\mathrm{CH}_{2}$ protons and a doublet of doublets due to $\mathrm{Glu}-\alpha \mathrm{CH}$; these were sharp and overlapping. Other resonances assigned to GS in this complex were broad, i.e. those of the Cys- $-\mathrm{BCH}_{2}$ protons and of $\mathrm{Glu}-\gamma \mathrm{CH}_{2}$ and $\mathrm{Glu}-\mathrm{\beta CH}_{2}$. No resonance due to $\mathrm{Cys}-\alpha-\mathrm{CH}$ was observable. At neutral $\mathrm{pH}^{\star}$ the resonances for $\mathrm{Glu}-\alpha \mathrm{CH}$ appeared as two doublet of doublets with a shift difference of $93.8 \mathrm{~Hz}$. The resonances for $\mathrm{Cys}-\mathrm{BCH}_{2}$ and $\gamma-\mathrm{Glu} \mathrm{CH}_{2}$ were broad at this $\mathrm{pH}^{*}$. Resonances due to protons of $\mathrm{C}_{6} \mathrm{H}_{5}$ groups of dppe were broad at both $\mathrm{pH}$ values. The resonances of the $\mathrm{CH}_{2}$ protons of dppe appeared as a set of three multiplets at acidic $\mathrm{pH}$ and at 
higher $\mathrm{pH}^{*}$ they gave rise to two multiplets. Added GSH gave rise to a separate set of sharp resonances and so exchange with free GSH was not the cause of the broadening. Instead, this is probably due to the presence of coordination equilibria in solution. Spectra for 2 and 4 were complicated by the presence of two isomeric products, as discussed above, and so are not reported.

${ }^{13} \mathrm{C}$ NMR data for the complexes $\left[\mathrm{Pd}\left(L_{-}-L^{\prime}\right)(G S) C l\right]\left(L_{-} L^{\prime}=\right.$ dppe $3 ; L^{\prime} L^{\prime}=$ dadpe 4$)$ at low and neutral $\mathrm{pH}^{*}$ values are given in Table 4(a). The assignments for complex 3 are made partly on the basis of a comparison of the changes in shifts of the resonances on increasing the $\mathrm{pH}^{*}$ from 1.8 to 7.2 with those observed for free $\mathrm{GSH},{ }^{19}$ and on the shifts noted previously for the Cys carbons of a $2: 1$ solution of $\mathrm{GSH}$ and $\mathrm{Hg}\left(\mathrm{NO}_{3}\right)_{2}$ in this $\mathrm{pH}^{*}$ range. ${ }^{20}$ At $\mathrm{pH}^{*}=7.2$, three sets of broad resonances were observed in the phenyl region corresponding to the $C_{6} \mathrm{H}_{5}$ carbons of dppe. The spectrum of the glutathione carbons of complex 4 was similar except that there were three resonances in the Cys $\alpha$-CONH region at $\delta=172.5,172.9$, and $173.3 \mathrm{ppm}$. The resonances at $\delta$ $=36.23$ and $30.93 \mathrm{ppm}$ are assigned to the aliphatic carbons adjacent to As and $P$, respectively. The latter resonance is a doublet with $\mathrm{J}_{\mathrm{P}-\mathrm{C}} 27 \mathrm{~Hz}$. There were several resonances in the aromatic region of the spectrum corresponding to $C_{6} \mathrm{H}_{5}$ of dadpe.

The coordination chemical shifts of the carbon atoms are listed in Table 4(b). The greatest shift observed is for the $\beta-\mathrm{CH}_{2}$ carbons of Cys which are shifted downfield by 7 to 8.6 p.p.m confirming coordination of the adjacent $\mathrm{S}$ atom. In addition the $\alpha-\mathrm{CH}$ carbons of Cys show an upfield shift of 1.6 p.p.m.. The resonances assigned to the Cys $\alpha-\mathrm{CONH}$ are also shifted upfield $(2.2$ to 2.4 p.p.m.) as are the resonances of the Glu $\gamma$-CONH (1.0 to 1.3 p.p.m.) suggesting interactions between the $\mathrm{NH}$ or $\mathrm{CO}$ groups and the metal centre. The coordination shifts are independent of $\mathrm{pH}^{*}$ with the exception of those of the $\mathrm{Glu} \alpha-\mathrm{COOH}$ which is higher at $\mathrm{pH}^{\star}=7.2$, perhaps because the coordination of the metal affects the $\mathrm{pK}_{\mathrm{a}}$ of the carboxylic acid group. The magnitudes of the coordination shifts for complexes 3 and 4 are similar, suggesting a similar 
coordination environment in both.

A previous study of $\mathrm{Pd}(\mathrm{II}) \mathrm{GSH}$ complexes suggested coordination via $\mathrm{S}$ and $\mathrm{N}$ of the Cys residue based on IR, UV-visible and analytical data, as well as the presence of bridging chloride ligands. ${ }^{4}$ Another study ${ }^{3}$ of a 1:1 complex suggested the formation of a seven-membered ring involving Pd, the terminal amino group and the deprotonated $\mathrm{NH}$ of the first peptide bond (Cys) in the case of the 1:1 Pd: GSH. Competition between $\mathrm{S}, \mathrm{N}, \mathrm{Cl}$ and $\mathrm{O}$ ligands is therefore likely to be facile on $\operatorname{Pd}(I I)$ accounting for the mixtures of species that are sometimes observed in solution.

The glutathione complexes, 3 and 4, $[\mathrm{Pd}(\mathrm{L}-\mathrm{L})(\mathrm{GS} . \mathrm{HCl}) \mathrm{Cl}]$, were tested for toxicity against three cell-lines: the murine cell-lines L1210 and ADJ/PC6, and the normal human ovarian cell-line $\mathrm{CH} 1$. The compounds had a relatively low toxicity against the murine cell-lines, Figure 1A, e.g. towards L1210 the $I C_{50}$ values for 3 and 4 were ca. 22 and $32 \mu \mathrm{M}$ respectively. However, they showed some tissue selectivity against $\mathrm{CH} 1$ cells with $\mathrm{IC}_{50}$ values in the region of 4 to $10 \mu \mathrm{M}$ (cf cisplatin $\mathrm{IC}_{50} 10^{-7} \mu \mathrm{M}$ against this cell-line). They were more cytotoxic towards L1210 cells than the bisthiolate complexes we have investigated previously, $[\mathrm{Pd}(\mathrm{dppe})(\mathrm{dmsa})]$ and $[\mathrm{Pd}(\mathrm{dadpe})(\mathrm{dmsa})]_{,}{ }^{2}$ and of comparable cytotoxicity to the square-planar dichloro complexes, $\left[\mathrm{Pd}\left(\mathrm{L}-L^{\prime}\right) \mathrm{Cl}_{2}\right]$, as shown in Figure 1B. However there is no increase in the cytotoxicity of the complexed ligand dppe or dadpe with respect to that of the free ligand towards this cell-line. Indeed, for dppe the ligand itself is significantly more toxic (by up to 5 times).

\section{CONCLUSION}

By introducing thiolato ligands into $\mathrm{Pd}(\mathrm{II})$ dppe and dadpe complexes, we have improved their aqueous solubility and retained their cytotoxicities in comparison to the parent dichloro complexes. For the L-cysteine complexes 1 and 2, IR and NMR showed the presence of S-bound cysteine ligands, and there was evidence for both monomers containing $\mathrm{S}, \mathrm{N}$ chelates and dimers with bridging $S$ in solution. Depending on the conditions, glutathione also bound strongly via $S$ in 

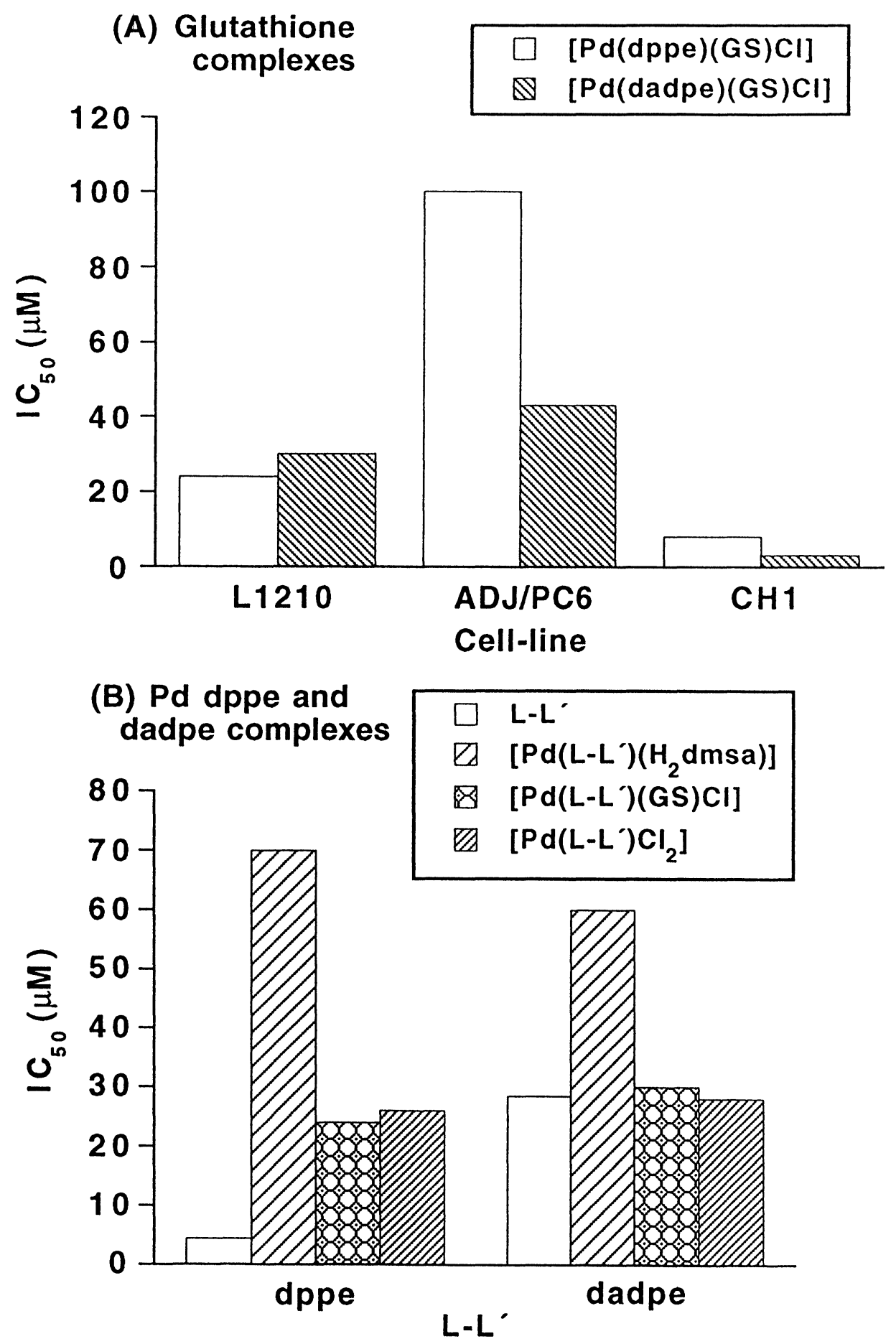

Figure 1.

(A) Cytotoxicities of $\mathrm{Pd}(\mathrm{II})$ glutathione complexes towards three cell lines

(B) Cytotoxicities of dppe and dadpe Pd(II) complexes of glutathione (GSH), dimercaptosuccinic acid $\left(\mathrm{H}_{2} \mathrm{dmsa}\right)$ towards $\mathrm{L} 1210$ cells compared to those of the free ligands dppe, dadpe, and their $\operatorname{Pd}(I I)$ dichloro complexes. 
complexes 3 and 4 and S-bridged complexes appeared to predominate in aqueous solution, but complicated equilibria were also detected with evidence for exchange between various coordination sites. Complexes with moderate cytotoxicity such as those described here, if they are also active in vivo, could be useful in combination therapy with established drugs such as cisplatin since they are likely to have a different mechanism of action.

\section{ACKNOWLEDGEMENTS}

We thank the Cancer Research Campaign, the Medical Research Council, University of London Intercollegiate Research Services and the Wolfson Foundation for their support for this work. We also thank Prof. K. Harrap and Dr. P. Goddard, Institute of Cancer Research, Sutton for carrying out the cytotoxicity experiments. One of us (E.G.F.) thanks the University of Santiago de Compostela and Xunta de Galicia, Spain for financial support.

\section{REFERENCES}

1. S.J. Berners-Price and P.J. Sadler, Struct. Bonding 70, 27 (1988)

2. O.M. Ni Dhubhghaill, P.S. Jarrett and P.J. Sadler, J. Chem.Soc. Dalton Trans. 1863 (1993)

3. L.D. Pettit and M. Bezer, Coord. Chem. Rev.. 61, 97 (1985)

4. S.T. Chow, C.A. McAuliffe, and B.J. Sayle, J. Inorg. Nucl. Chem. 37, 451 (1975)

5. G.D. Zegzhda and T.V. Zegzhda, Russ. J. Inorg. Chem.. 23, 1826 (1978)

6. D. L. Rabenstein, S. J. Backs, A.A. Isab, J. Am. Chem. Soc. 103, 2836 (1981)

7. W. Kadima and Dallas L. Rabenstein, J. Inorg. Biochem. 38, 277 (1990)

8. M.T. Razi, G. Otiko, and P.J. Sadler in Platinum, gold and other metal chemotherapeutic agents, ACS Sym. Ser. 209, 371 (1983).

9. D. L. Rabenstein and M.T. Fairhurst, J. Am. Chem. Soc. 97, 2086 (1975) 
10. R.S. Reid and D.L. Rabenstein, Can. J. Chem. 59, 1505 (1981);

R.S. Reid and D.L. Rabenstein, J. Am. Chem. Soc. 104, 6733 (1982)

11. D.L. Rabenstein and R.S. Reid, Inorg. Chem. 23, 1246 (1984);

B. V. Cheesman, A. P. Arnold, and D. L. Rabenstein, J. Am. Chem. Soc. 110, 6359 (1988)

12. K. Miyoshi, Y. Sugiura, K. Ishizu, Y. litaka, and H. Nakamura, J. Am. Chem. Soc. 102, $6130(1980)$

13. L.P. Battaglia, A. Bonamartini Corradi, C. Grasselli Palmieri, M. Nardelli, and M.E. Vidoni Tani, Acta Cryst. B29, 762 (1973)

14. A. Allain, M. Kubiak, B. J. Jezowska-Trzebiatowska, H. Kozlowski, and T. Glowiak, Inorg. Chim. Acta 46, 127 (1980)

15. M. Kubiak, A. Allain, B. J. Jezowska-Trzebiatowska, T. Glowiak, and H. Kozlowski, Acta Cryst. B36, 2246 (1980)

16. G.K. Anderson, H.C. Clark, and J.A. Davies, Inorg. Chem. 20, 3607 (1981)

17. D.S. Gill, in Platinum Coordination Complexes in Cancer Chemotherapy, M.P. Hacker, E.B. Douple, I.H. Krakoff, Eds., Martinus Nijhoff, Boston, p 267 (1984).

18. P. Castan, E. Colacio-Rodriguez, A.L. Beauchamp, S. Cros and S. Wimmer, J. Inorg. Biochem. 38, 225 (1990)

19. G. Jung, E. Breitmaier, and W. Voelter, Eur. J. Biochem. 24, 438 (1972)

20. B.J. Fuhr and D.L. Rabenstein, J. Amer. Chem. Soc. 95, 6944 (1973)

Received: June 6, 1994 - Accepted: June 23, 1994 - Received in camera-ready format: September 15, 1994 